\title{
The June 2013 flood in the Upper Danube Basin, and comparisons with the 2002, 1954 and 1899 floods
}

\author{
G. Blöschl, T. Nester, J. Komma, J. Parajka, and R. A. P. Perdigão \\ Institute of Hydraulic Engineering and Water Resources Management, Vienna University of Technology, Vienna, Austria \\ Correspondence to: G. Blöschl (bloeschl@hydro.tuwien.ac.at)
}

Received: 5 July 2013 - Published in Hydrol. Earth Syst. Sci. Discuss.: 19 July 2013

Revised: 15 November 2013 - Accepted: 5 December 2013 - Published: 20 December 2013

\begin{abstract}
The June 2013 flood in the Upper Danube Basin was one of the largest floods in the past two centuries. An atmospheric blocking situation produced precipitation exceeding $300 \mathrm{~mm}$ over four days at the northern rim of the Alps. The high precipitation, along with high antecedent soil moisture, gave rise to extreme flood discharges in a number of tributaries including the Tiroler Ache, Saalach, Salzach and Inn. Runoff coefficients ranged from 0.2 in the Bavarian lowlands to 0.6 in the Alpine areas in Austria. Snowfall at high altitudes (above about $1600 \mathrm{~m}$ a.s.l.) reduced the runoff volume produced. Precipitation was distributed over two blocks separated by a few hours, which resulted in a single peak, long-duration flood wave at the Inn and Danube. At the confluence of the Bavarian Danube and the Inn, the small time lag between the two flood waves exacerbated the downstream flood at the Danube. Because of the long duration and less inundation, there was less flood peak attenuation along the Austrian Danube reach than for the August 2002 flood. Maximum flood discharges of the Danube at Vienna were about $11000 \mathrm{~m}^{3} \mathrm{~s}^{-1}$, as compared to 10300,9600 and $10500 \mathrm{~m}^{3} \mathrm{~s}^{-1}$ in 2002, 1954 and 1899 , respectively. This paper reviews the meteorological and hydrological characteristics of the event as compared to the 2002, 1954 and 1899 floods, and discusses the implications for hydrological research and flood risk management.
\end{abstract}

\section{Introduction}

In June 2013 a major flood struck the Upper Danube Basin causing heavy damage along the Danube and numerous tributaries. The city centre of Passau (at the confluence of the Danube, Inn and Ilz) experienced flood levels that were similar to the highest recorded flood in 1501. Extraordinary flood discharges were recorded along the Saalach and Tiroler Ache at the Austrian-Bavarian border. The flood discharge of the Danube at Vienna exceeded those observed in the past two centuries.

The June 2013 flood comes at a time with an amazing history of recent large floods. In August 2005, the Danube tributaries in western Tyrol and the south of Bavaria were flooded through extensive precipitation and high antecedent soil moisture (BLU, 2006). In August 2002, a major flood hit the entire Upper Danube Basin. Damage was most severe at the northern tributaries of the Austrian Danube at the Czech border, in particular the Aist and Kamp rivers. At the Kamp, flood discharges were almost three times the largest flood in the century before (Gutknecht et al., 2002). Flooding was extensive along the entire Austrian Danube which resulted in the use of the term "century flood". The preceding decades were relatively flood-poor at the Danube aside from more minor floods in 1991, 1966 and 1965; however a very large flood occurred in July 1954 with major damage along the entire Upper Danube. Again, a couple of decades with almost no floods preceded. The flood of September 1899, then, was the largest measured flood along the Danube with $48 \mathrm{~h}$ precipitation totals exceeding $200 \mathrm{~mm}$ over an area of $1000 \mathrm{~km}^{2}$ (Kresser, 1957). Major floods occurred in August 1897, February 1862 and October 1787 with a long record of previous events (Kresser, 1957; Pekarová et al., 2013).

The aim of this paper is to analyse the causal factors of the June 2013 flood including the atmospheric situation, runoff generation and the propagation of the flood wave along the Danube and tributaries. Given the extraordinary nature of the 2013 flood, the paper also compares this flood with the largest Upper Danube floods in the past two centuries, i.e. the floods in August 2002, July 1954 and September 1899. 


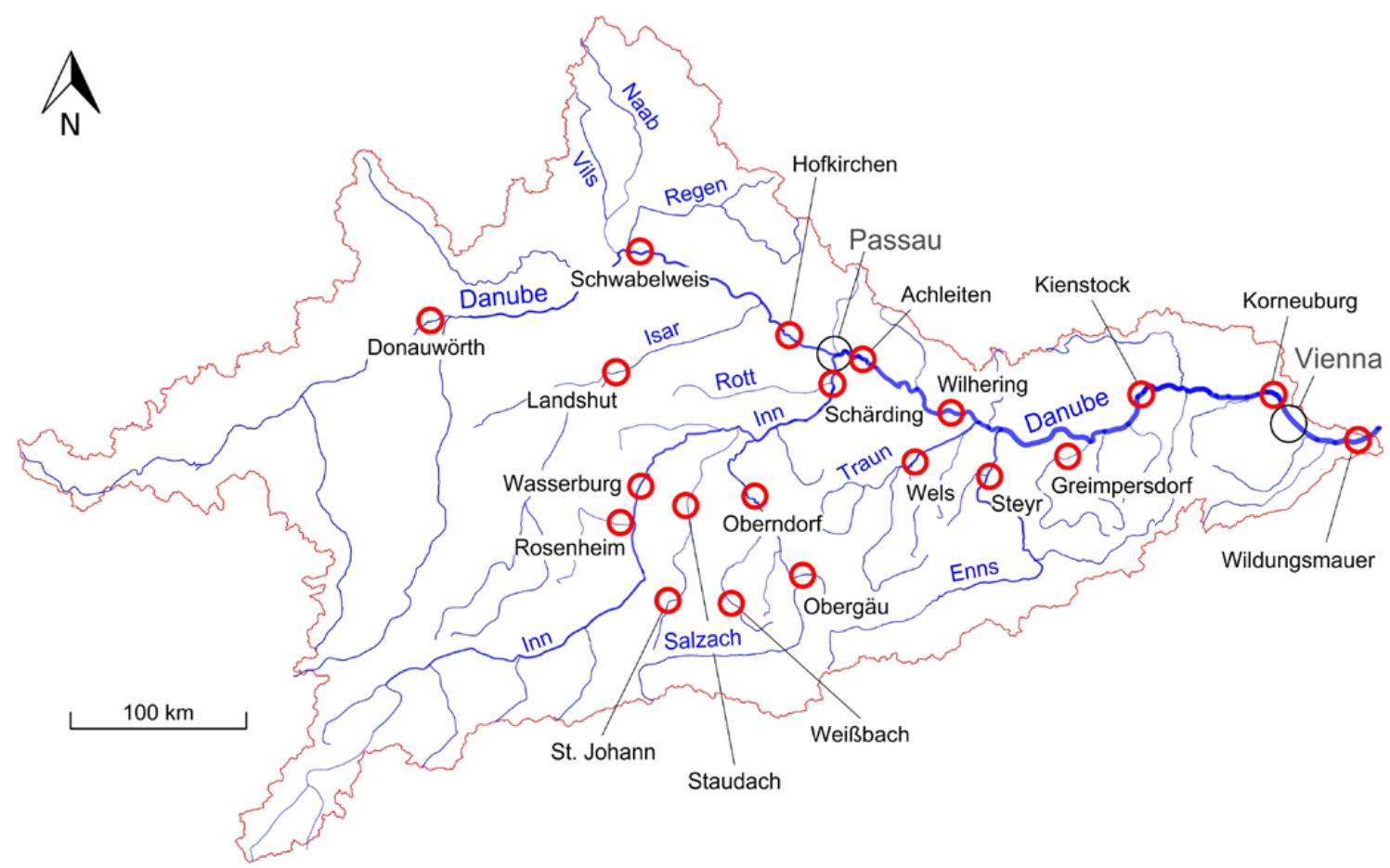

Fig. 1. The Upper Danube Basin upstream of Wildungsmauer. Red circles indicate stream gauges used in this paper. Black circles indicate the cities of Vienna and Passau. For catchment areas and mean elevations of the catchments see Appendix A.

\section{The Upper Danube Basin}

The Upper Danube Basin consists of two main subcatchments, the Bavarian Danube and the Inn. The Bavarian Danube catchment in the northwest comprises lowlands with diverse geology. Quaternary and Tertiary deposits prevail, which are highly permeable and provide large subsurface storage in porous aquifers, and there is also karst in the northwest. Some of the tributaries, such as the Lech and Isar, originate from the Alps. Elevations range from 310 to $3000 \mathrm{~m}$ a.s.l. Mean annual precipitation ranges from 650 to more than $2000 \mathrm{~mm} \mathrm{yr}^{-1}$, resulting in mean annual runoff depths from 100 to $1500 \mathrm{~mm} \mathrm{yr}^{-1}$ (BMU, 2003). The Inn catchment, further in the south, drains a large part of the Austrian Alps. An important tributary is the Salzach. Geologically, the Inn catchment mainly consists of the northern Calcareous Alps, the Palaeozoic Greywacke zone further in the south and the Crystalline zone along the ridge of the eastern Alps (Janoschek and Matura, 1980). Elevations range from 310 to $3800 \mathrm{~m}$. Mean annual precipitation ranges from 600 to more than $2000 \mathrm{~mm} \mathrm{yr}^{-1}$, resulting in mean annual runoff depths from 100 to $1600 \mathrm{~mm} \mathrm{yr}^{-1}$ (Parajka et al., 2007; Nester et al., 2011).

The Bavarian Danube and the Inn join at Passau. Downstream of the confluence, along the Austrian reach of the Danube, southern tributaries from the high rainfall areas in the Calcareous Alps include the Traun, Enns and Ybbs. The northern tributaries from the lower rainfall areas with mainly granitic geology include the Aist and Kamp. Flood protection levees have been built along many tributaries and the Danube itself during the 19th and 20th century. The total catchment area of the Danube at Wildungsmauer downstream of Vienna is $104000 \mathrm{~km}^{2}$. Figure 1 shows the catchments discussed in this paper, and Appendix A gives their main characteristics.

\section{Large-scale atmospheric conditions}

The 2013 flood was produced by an atmospheric situation that is typical of floods in the Upper Danube. In the second half of May 2013 the planetary waves of the large-scale atmospheric flow regime in the Northern Hemisphere exhibited stationary behaviour as the mean eastward zonal flow decelerated and no longer exceeded the westward propagation of the Rossby waves produced by the latitude-varying Coriolis effect (Rossby, 1939; Holton, 2004). The stationary nature of the systems is illustrated by the five-day moving averages of the geopotential height centred on 26 May and 30 May 2013 in Fig. 2. The shapes of the system centres in Fig. 2 are circular or near-circular, indicating that these centres have barely moved during the five-day averaging periods. The persistence is further highlighted by the similarity of the two patterns. Figure 2 shows the situation at $1000 \mathrm{hPa}$; standing waves were also observed at $500 \mathrm{hPa}$. The largescale stationary flow regime led to the blocking of a number of synoptic systems including the Azores anticyclone, which 

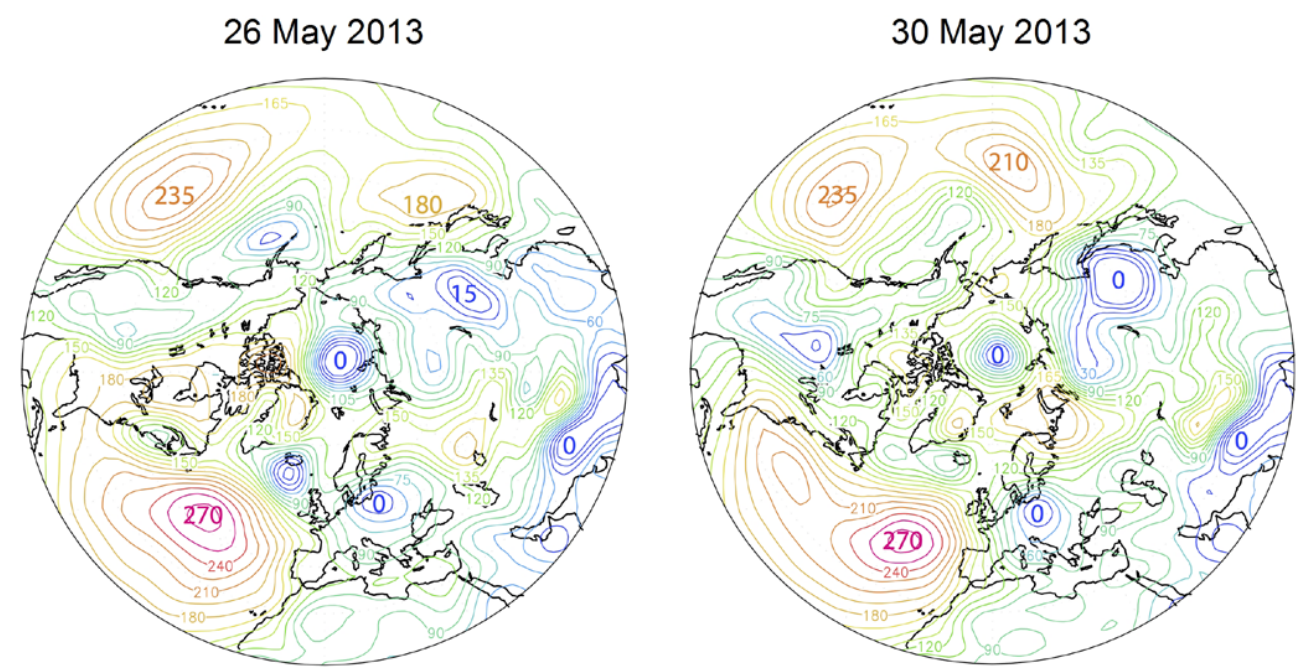

Fig. 2. Geopotential height fields (in meter) at $1000 \mathrm{hPa}$ of the Northern Hemisphere for latitudes above 20 degrees. Five-day moving averages, centred on 26 May and 30 May 2013. The geopotential height difference between consecutive isolines is $15 \mathrm{~m}$. Based on the NCEP-NCAR Reanalysis data sets (Kistler et al., 2001).

extended over a particularly vast expanse of the North Atlantic, and the Siberian anticyclone, which extended southwest of its usual position, blocking the eastward progression of the central European low. The moisture brought from the northwestern Atlantic caused rainfall in the Upper Danube Basin from 18 to 27 May. As the system positioned itself over the Alpine area, its cyclonic, anticlockwise rotation and spatial extent allowed it to collect additional moisture from the Mediterranean, feeding in particular from local depressions in the Ligurian and Adriatic seas (Fig. 3), and advecting that additional moisture cyclonically into central Europe. This regional cyclonic track is known in central Europe as " $\mathrm{Vb}$ ", after van Bebber (1891). When the cyclonically advected air mass reached the northern fringe of the eastern Alps, persistent, heavy precipitation ensued, lasting from 30 May to 4 June 2013.

The atmospheric situation of the August 2002 flood event was similar in that the Northern Hemisphere exhibited stationarity, though not in such a pronounced way as in 2013. During the first week of August a strong synoptic depression was positioned over southern Britain and the Low Countries, bringing Atlantic and North Sea moisture into northwestern and central Europe, sweeping the region with heavy rain during the period 6-7 August. Then, the depression progressed on a southeast track, causing a break in rainfall of about three days, and settled in central Europe. The easterly progress was blocked by a high pressure swath from Scandinavia to the Caspian Sea akin to the standing high pressure over western Russia in 2013. The persistence and extent of the central European depression during the second week of August allowed cyclonic circulation to extend as far south as the Ligurian and Adriatic seas ( $\mathrm{Vb}$ situation), again advecting air mass in an arc to the north, resulting in heavy precipitation from 7 to 11 August. However, relative to 2013 the rainfall patterns were further to the east due to the position and extent of the low pressure system, advecting Mediterranean moisture in a more pronounced $\mathrm{Vb}$ trajectory (namely from the Ligurian sea to the Vienna Basin).

The situation of the July 1954 flood, again, was characterised by a large-scale stationary situation with a blocked Azorean high that extended abnormally north which brought arctic moisture into northwestern Europe, causing a temperature drop and precipitation in the Alps with snowfall at elevations above $800 \mathrm{~m}$ on 7 July. The stationarity of the largescale situation led not just to a large-scale blocking (as in 2013) but also to a detachment of a low pressure system from the upper tropospheric flow over the Alps, leading to substantial precipitation on 8 and 9 July.

The situation in September 1899 was quite different from those in 2013, 2002 and 1954 as there was no large-scale atmospheric stationarity. In early September, the north Atlantic anticyclone extended far to the north thus bringing moisture into Europe from the northwest. However, unlike in the other years, there was a strong surface depression in the Baltic area that brought additional moisture from the north as well. A low pressure system formed and positioned itself over the Balkan, merging with another system from the southern Adriatic. This produced an exceptionally large low pressure system extending from North Africa to the Baltic and from the western Alps to the Black Sea. Heavy precipitation ensued from 9 to 11 September. The very large spatial extent of this low pressure system gathered additional moisture from a vast expanse of the Mediterranean and the Baltic. The strong pressure gradient over the Alps (Fig. 3) led to strong currents and updraft, triggering excessive precipitation at the northern fringe of the Alps on 12 and 13 September. Note that 


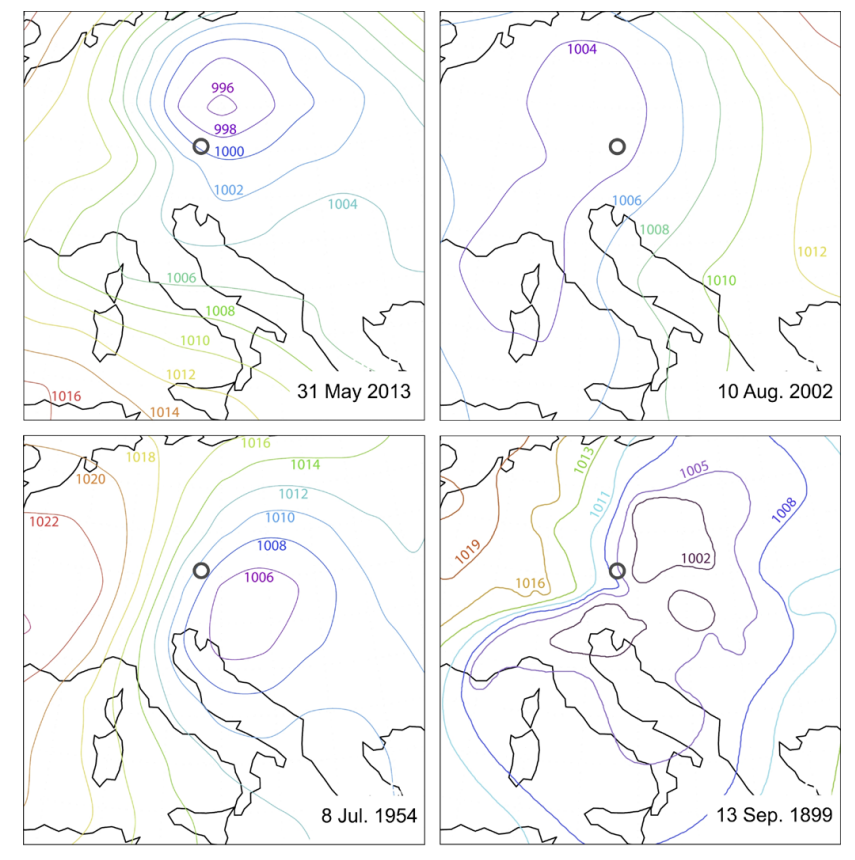

Fig. 3. Sea level pressure (hPa) in central Europe on 31 May 2013 (00:00), 10 August 2002 (12:00), 8 July 1954 (00:00), 13 September 1899 (06:00) (all times in UTC). 2013, 2002 and 1954 are based on the NCEP-NCAR Reanalysis, while 1899 is from Lauda (1900). Circles indicate location of Passau. Times have been chosen as to be most relevant for the precipitation production.

the pressure map of Lauda (1900) is based on more than 100 stations in Europe, so it shows considerable spatial detail.

\section{Local meteorological conditions (precipitation and snow)}

\subsection{Regional precipitation patterns of the 2013 flood}

Climatologically, May 2013 was one of the three wettest months of May in the past $150 \mathrm{yr}$ in the Upper Danube Basin. The north of the catchment was particularly wet at the end of the month. Regensburg (near the Schwabelweis gauge in Fig. 1), for example, had $139 \mathrm{~mm}$ of precipitation in May 2013 as compared to the long-term May mean of $68 \mathrm{~mm}$ (period 1976-2011). Lower than average air temperatures resulted in low evaporation rates. The end-of-May soil moisture exceeded all end-of-May values over the period 1962 to 2012 considered in the simulations of BfG (2013) that were conducted as a function of climate variables and soil characteristics. Also, ground water levels were particularly high as indicated by numerous piezometers in the region. Further in the south, the soils were still relatively wet, although the situation was less extreme. Lofer (near the Weißbach gauge in Fig. 1), for example, had $209 \mathrm{~mm}$ of precipitation in May 2013 as compared to the long-term May mean of
$140 \mathrm{~mm}$. This means that at the beginning of the event, the soils were wet throughout the Upper Danube Basin, although there was a pronounced north-south gradient with higher soil moisture in the north, and lower soil moisture in the south.

Heavy precipitation started on 29 May in the northern part of the Bavarian Danube catchment around the city of Regensburg. From 29 May to 4 June precipitation totals of $95 \mathrm{~mm}$ were observed in Regensburg, $94 \mathrm{~mm}$ in Straubing, and $112 \mathrm{~mm}$ at Großer Arber to the east of Regensburg. In the southern part of the Bavarian Danube catchment and the Inn catchment, heavy precipitation started on 30 May and lasted until 2 June 2013, with smaller intensities on 3 and 4 June. From 29 May to 4 June precipitation totals of $232 \mathrm{~mm}$ were observed in Lofer, $244 \mathrm{~mm}$ in Kössen $(25 \mathrm{~km}$ northwest of Lofer) and $270 \mathrm{~mm}$ in Samerberg (40 km northwest of Lofer) indicating heavy precipitation over a substantial area. Figure 4 (top left) shows the spatial pattern of precipitation for a period of seven days (29 May to 4 June, 2013). As indicated in the figure, precipitation was highest along the northern ridge of the Alps in Austria (Tirol, Salzburg and Upper Austria) and there was also very significant precipitation further in the north. Precipitation interpolated between the rain gauges based on weather radar exceeded $300 \mathrm{~mm}$ during this time period (Fig. 4).

As an example, Fig. 5 shows the evolution of catchment precipitation during May and the first days of June 2013 for the Weißbach catchment, a tributary to the Salzach (Fig. 1) just $10 \mathrm{~km}$ south of Lofer. The catchment was selected because of its large precipitation totals. Catchment precipitation was estimated from the gridded data as in Fig. 4. In this catchment, May 2013 precipitation was $184 \mathrm{~mm}$, and the event precipitation from 30 May to 2 June was an additional $175 \mathrm{~mm}$. The event consisted of two main precipitation blocks separated by a few hours of no or lower intensity rain. These two rain blocks were apparent over most of the Upper Danube Basin.

Air temperatures in the first three weeks of May were somewhat lower than the long-term average in the Upper Danube Basin. On 20 May, air temperatures started to decrease but recovered a few days later. A significant drop in air temperatures occurred on 29 May. Because of this, there was significant snowfall at the high-elevation stations in the Alps. The snow depths at Enzingerboden station (1480 m a.s.l., $40 \mathrm{~km}$ south of Weißbach) on the mornings of 30 and 31 May were 5 and $7 \mathrm{~cm}$, respectively. On 31 May air temperatures increased again, which melted the snow below, approximately, $1800 \mathrm{~m}$ a.s.l. The snow depths at the Rudolfshütte station (2317 m a.s.l., near Enzingerboden) from 30 May to 2 June were $95,120,130,190 \mathrm{~cm}$, respectively.

The bottom panel of Fig. 5 shows the catchment mean air temperature (dark red line) of the Weißbach catchment. The figure indicates that during the event, on average in the catchment, the temperatures were barely above zero. The high-elevation temperatures dropped significantly below zero. The Loferer Alm temperatures (1623 m a.s.l., orange 

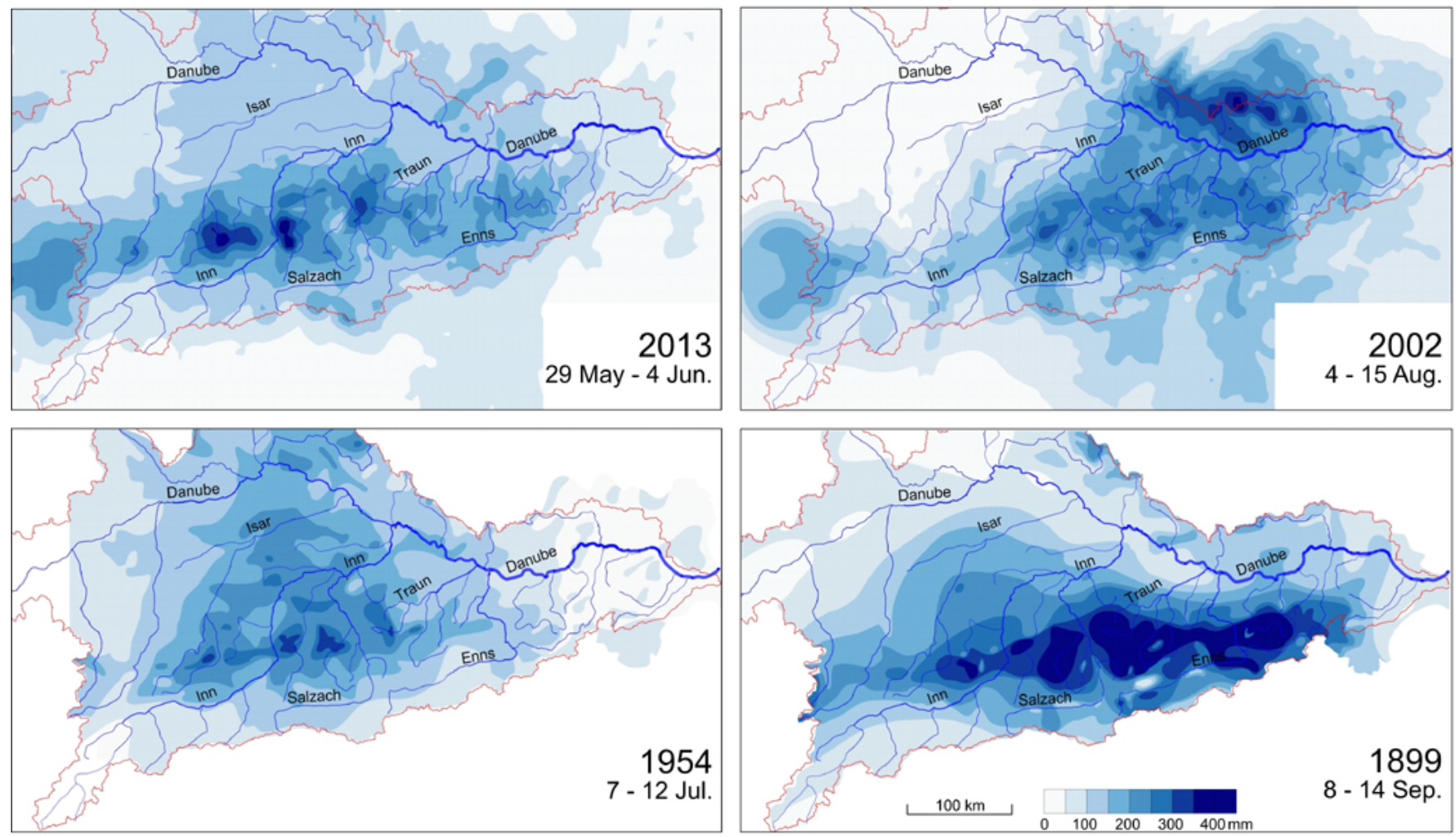

Fig. 4. Observed precipitation totals of four large flood events in the Upper Danube Basin: 29 May 00:00 to 4 June 2013 24:00; 4 August 00:00 to 15 August 2002 24:00; 7 July to 12 July 1954, and 8 September to 14 September 1899 (based on available daily records, 07:00 to 07:00). 2013 and 2002 are based on rain gauge data interpolated by the INCA method using radar (Haiden et al., 2011). 1954 and 1899 are based on rain gauge data interpolated manually from about 600 stations within the Danube Basin (HZB, 1955; Lauda, 1900). Red line indicates the Upper Danube catchment boundary above Wildungsmauer.

line) dropped to $-2{ }^{\circ} \mathrm{C}$ on 30 May. Overall, $25 \%$ of the Weißbach catchment is above an elevation of $1623 \mathrm{~m}$ a.s.l. indicating that a significant fraction of precipitation fell as snow, reducing the liquid precipitation available for flood runoff. However, some of the snow on the ground had melted on 1 June, adding to the available event water.

\subsection{Comparison with the 2002, 1954 and 1899 floods}

It is now of interest to compare the meteorological conditions of the 2013 flood with those of the previous floods. The August 2002 flood was a double event. The two rainfall peaks (7 August and 11-12 August) were separated by four days rather than a few hours as in the case of 2013. This was because of the less stationary, large-scale atmospheric situation which led to a movement of the atmospheric system between two distinct precipitation blocks. There was less precipitation in the catchment of the Bavarian Danube, but significantly more over the northern tributaries to the Austrian Danube at the Czech border such as the Kamp and the Aist (Fig. 4; Ulbrich et al., 2003). In the $620 \mathrm{~km}^{2}$ Kamp catchment there were 200 and $115 \mathrm{~mm}$ of precipitation during the two events, respectively (Gutknecht et al., 2002). The first event substantially increased the antecedent soil moisture for the second event (Komma et al., 2007). In fact, the soils were virtually saturated at the beginning of the second event which is very unusual for the sandy soils in the area. Air temperatures were rather high and the catchments most affected do not exceed $1000 \mathrm{~m}$ in elevation, so snow did not play a significant role during this event (Godina et al., 2003).

The three months preceding the 1954 flood were wetter than the mean. The actual event consisted of two precipitation blocks, a minor event during 1-2 July, and a more extreme block during 7-12 July. The defining feature of the event was the spatial distribution with unusually high precipitation in the north of the Upper Danube similar to, but exceeding that of the 2013 flood. During 7-12 July, $208 \mathrm{~mm}$ were observed in Munich and $432 \mathrm{~mm}$ in Jachenau, some $50 \mathrm{~km}$ south of Munich. At the northern fringe of the Alps, in Lofer, $257 \mathrm{~mm}$ of precipitation were recorded for the same period. The two-day maxima (7-8 July) at Lofer and Reichenhall were 233 and $179 \mathrm{~mm}$, respectively. Both stations are within the Saalach catchment, a tributary to the Salzach. The first event increased antecedent soil moisture so that the precipitation of the second event fell on wet soils. However, substantial snow was retained in the Alpine catchments 

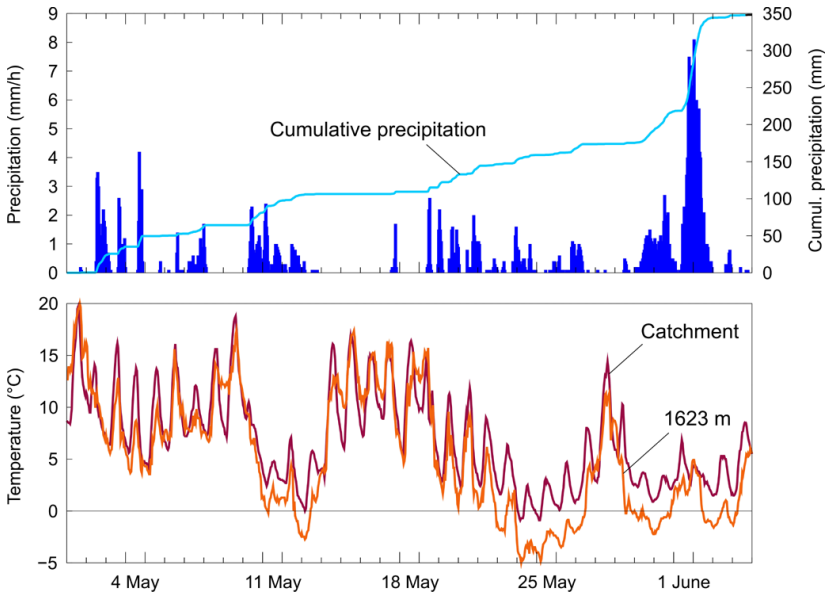

Fig. 5. (top) Catchment precipitation for the Weißbach catchment $\left(567 \mathrm{~km}^{2}\right)$ in May and June 2013 (dark blue shows hourly intensities, light blue cumulative precipitation). (bottom) Catchment average temperatures for the Weißbach catchment (dark red) and air temperature at the Loferer Alm station (1623 m a.s.l., orange).

and did not contribute to flood runoff. There was snow accumulation down to $800 \mathrm{~m}$ a.s.l. For example, in Dienten ( $1200 \mathrm{~m}$ a.s.l., some $20 \mathrm{~km}$ southeast of Weißbach) snow depths increased from 20 to $77 \mathrm{~cm}$ on 8 July and little melt occurred on the following days (HZB, 1955).

The September 1899 flood was hydrologically quite different from the three other events. The 1898/1899 winter had been exceptionally dry with very little snow. Similarly, summer 1899 was unusually dry. August precipitation was about one-third lower than the long-term average. For example, in Waidring near Lofer, 1899 August precipitation was $114 \mathrm{~mm}$ as compared to the long-term mean over the previous decades of $201 \mathrm{~mm}$. Because of this, subsurface stores had been depleted (as indicated by the low groundwater levels presented in Lauda, 1900) and soil moisture was low at the beginning of the event. In contrast, the event precipitation was enormous (Fig. 4). Weißbach recorded $515 \mathrm{~mm}$ in the period from 8 to 14 September. Not only was the total precipitation beyond any observations but also the spatial extent of the event. The $48 \mathrm{~h}$ precipitation totals exceeded $200 \mathrm{~mm}$ over an area of $1000 \mathrm{~km}^{2}$ (Kresser, 1957). Snow also played a role. Snow accumulated above about $1400 \mathrm{~m}$ a.s.l. which reduced the liquid water input to the event. Most of the precipitation fell in the Inn, Salzach, Traun and Enns catchments. There was a much smaller contribution from the Bavarian Danube (Lauda, 1900).

\section{Runoff generation}

\subsection{Runoff generation of the 2013 flood}

Table 1 gives the event characteristics of a number of catchments with particularly high event precipitation. The catchments drain into the Inn (Rosenheim, St. Johann, Staudach), Salzach (Weißbach, Obergäu) or directly into the Austrian Danube (Wels) (see Fig. 1) The event precipitation was of the same order of magnitude as the antecedent precipitation in May, ranging from $160 \mathrm{~mm}$ in the Obergäu catchment to $231 \mathrm{~mm}$ in the Rosenheim catchment. Because of the relatively high antecedent precipitation, and hence soil moisture, the runoff coefficients are quite large. They ranged between 0.42 and 0.56 . However, these runoff coefficients are not unusually high. For comparison, the average runoff coefficients in these catchments for events with more than $50 \mathrm{~mm}$ precipitation are given. In Obergäu and Wels, the runoff coefficients of the 2013 event are 0.58 and 0.56 and thus very similar to the average runoff coefficients of all large events (precipitation $>50 \mathrm{~mm}$ ) in these catchments. In Weißbach the runoff coefficient of the 2013 event is 0.42 , which is somewhat lower than the averages of the large events, in spite of the relatively wet antecedent conditions. This is because part of the precipitation fell as snow and remained as snow cover until after the event in the highest parts of the catchment.

Figure 6 (left) shows the 2013 event for the Weißbach catchment in more detail. The cumulative precipitation illustrates the two precipitation blocks. The first block of $45 \mathrm{~mm}$ started on 30 May around midday and lasted until the evening of 31 May. The second block of $130 \mathrm{~mm}$ started on 1 June in the afternoon and lasted until the evening of 2 June. The first block of precipitation led to a slight increase in runoff, while the second block of precipitation increased the event runoff to a total of $74 \mathrm{~mm}$. There are two reasons for the very small response to the first precipitation block. The first is the soil storage left at the beginning of the event. The second is the temperatures which were below $0^{\circ} \mathrm{C}$ in one-third of the catchment (light green line in Fig. 6) so there was significant snowfall. During the second block of precipitation the percentage of the catchment with temperatures below $0^{\circ} \mathrm{C}$ was lower, particularly at the beginning of the second block when it was warmer. The figure suggests that, over the entire event, around $25 \%$ of the precipitation, or $44 \mathrm{~mm}$, fell as snow and the remaining $131 \mathrm{~mm}$ fell as rain. If one only counts rainfall, the associated runoff coefficient is 0.56 which is more in line with the antecedent soil moisture. However, it is likely that some (but not all) of the snow that fell at the beginning of the event melted during the event. The situation in the Weißbach is typical of the Alpine high rainfall catchments during the June 2013 flood. St. Johann and Staudach (Table 1) give similar figures but somewhat higher runoff coefficients because of the lower fraction of snowfall.

In the Bavarian Danube catchment there was also substantial precipitation, albeit with a strong south-north gradient and precipitation that started earlier. Figure 6 (right) shows the cumulative event precipitation and event runoff for the Hofkirchen catchment $\left(45610 \mathrm{~km}^{2}\right)$. Catchment precipitation was significantly lower than in the Weißbach with a total of $116 \mathrm{~mm}$ since the northwest of the catchment contributed less precipitation than the southern Alpine section. 
Table 1. Characteristics of the June 2013 flood in small catchments in the Upper Danube Basin with particularly high event precipitation. Catchment precipitation in May ( $P$ May, average 1976-2011), May 2013 ( $P$ May 2013, 1-29 May 2013), during the event $(P$ event 2013, 30 May-4 June, 2013), event runoff of 2013 flood, runoff coefficient of 2013 flood, mean runoff coefficients for events with precipitation $>50 \mathrm{~mm}$, and 2013 peak runoff. For catchment locations see Fig. 1. Runoff coefficients are from Merz and Blöschl (2009) and Merz et al. (2006).

\begin{tabular}{|c|c|c|c|c|c|c|c|c|c|}
\hline Catchment & Stream & $\begin{array}{l}\text { Catchment } \\
\text { area }\left(\mathrm{km}^{2}\right)\end{array}$ & $\begin{array}{r}P \text { May } \\
\text { average } \\
(\mathrm{mm})\end{array}$ & $\begin{array}{r}P \text { May } \\
2013 \\
(\mathrm{~mm})\end{array}$ & $\begin{array}{r}P \text { event } \\
2013 \\
(\mathrm{~mm})\end{array}$ & $\begin{array}{r}\text { Event } \\
\text { runoff } \\
2013 \\
(\mathrm{~mm})\end{array}$ & $\begin{array}{r}\text { Runoff } \\
\text { coefficient } \\
2013 \\
(-)\end{array}$ & $\begin{array}{r}\text { Mean } \\
\text { Runoff } \\
\text { coefficient } \\
(-)\end{array}$ & $\begin{array}{r}\text { Peak } \\
\text { runoff } \\
2013 \\
\left(\mathrm{~m}^{3} \mathrm{~s}^{-1}\right)\end{array}$ \\
\hline Rosenheim & Mangfall & 1090 & 106 & 231 & 228 & 100 & 0.44 & 0.45 & 530 \\
\hline St. Johann & Kitzbüheler Ache & 330 & 114 & 210 & 190 & 96 & 0.50 & 0.38 & 290 \\
\hline Staudach & Tiroler Achen & 944 & 112 & 216 & 226 & 130 & 0.58 & 0.49 & 950 \\
\hline Weißbach am Lofer & Saalach & 567 & 114 & 184 & 175 & 74 & 0.42 & 0.47 & 470 \\
\hline Obergäu & Lammer & 395 & 111 & 205 & 160 & 93 & 0.58 & 0.58 & 600 \\
\hline Wels & Traun & 3425 & 103 & 192 & 187 & 105 & 0.56 & 0.57 & 1650 \\
\hline
\end{tabular}

However, relative to previous events, the precipitation in this catchment was still enormous. At the scale of this catchment, the two precipitation blocks are still visible, but they were only separated by $12 \mathrm{~h}$. The first block consisted of $45 \mathrm{~mm}$, the second of $61 \mathrm{~mm}$, and there was some early precipitation of $10 \mathrm{~mm}$ on 29 May. Temperatures were above zero in almost the entire catchment. Only $31 \mathrm{~mm}$ out of the $116 \mathrm{~mm}$ precipitation contributed to the runoff, resulting in a runoff coefficient of 0.27 . This is because of the highly permeable soils and the large storage capacity in the catchment in spite of the high antecedent soil moisture. The cumulative runoff depth in Fig. 6 right (red line) indicates the substantial delay between precipitation and runoff. Essentially all the precipitation was stored in the catchment at the inception of runoff.

\subsection{Comparison with previous floods}

It is now of interest to put the 2013 event for those areas where rainfall was particularly large into the context of the longer-term flood history in the area. Figure 7 (left) shows the extreme value statistics for $48 \mathrm{~h}$ precipitation of the Lofer rain gauge located near the Weißbach stream gauge. In June 2013, the two-day precipitation was the highest since beginning of the data set in 1961. Around $173 \mathrm{~mm}$ of precipitation were observed in two days at this station, as compared to $122 \mathrm{~mm}$ during the August 2002 flood. Based on a Gumbel distribution, this precipitation total corresponds to a return period of about $70 \mathrm{yr}$. The right panel of Fig. 7 shows the extreme value statistics of the flood peaks at the Weißbach stream gauge. With a peak runoff of $480 \mathrm{~m}^{3} \mathrm{~s}^{-1}$ the 2013 flood was the highest since beginning of the observations in 1959. The associated return period is around $100 \mathrm{yr}$. The 2002 flood peak was slightly lower, with a peak discharge of $400 \mathrm{~m}^{3} \mathrm{~s}^{-1}$. The return period on the order of $100 \mathrm{yr}$ for the June 2013 flood peak applies to a number of catchments in the area, in particular those at the Tiroler Achen und Saalach (Table 1, Fig. 1), and produced flood discharges with return periods of about $100 \mathrm{yr}$ at the downstream reaches along the Salzach and Inn.

At the small catchment scale, the August 2002 flood was most severe in the Kamp catchment at the Austrian-Czech border. In the Kamp and nearby catchments, the soils are sandy and thus much more permeable than the catchments of Table 1. Because of this, the runoff coefficients are usually quite low. For the Kamp at Zwettl catchment $\left(620 \mathrm{~km}^{2}\right)$ the average runoff coefficient (for event precipitation $>50 \mathrm{~mm}$ ) is 0.20 (Merz et al., 2006). Due to the large rainfall depths of the 2002 event ( 200 and $115 \mathrm{~mm}$ from the two events) soils did become saturated, leading to runoff coefficients of 0.41 and 0.58 for the two events, respectively (Komma et al., 2007) which is almost three times the average. The resulting flood peak was $460 \mathrm{~m}^{3} \mathrm{~s}^{-1}$ (as compared to the second largest peak of $170 \mathrm{~m}^{3} \mathrm{~s}^{-1}$ since beginning of the record in 1896) which made the 2002 flood at the Kamp locally substantially more unusual than the 2013 flood in the Weißbach and nearby catchments (Merz and Blöschl, 2008a, b; Viglione et al., 2010, 2013).

The 1954 flood exhibited significant antecedent precipitation and a pre-event which increased antecedent soil moisture. At the Lofer station, the maximum two-day precipitation total was $233 \mathrm{~mm}$ (7-8 July, 1954) although a significant part of it fell as snow as there was snowfall down to $800 \mathrm{~m}$ a.s.l. which reduced runoff production (HZB, 1955).

Prior to the 1899 flood, subsurface storage was depleted and soils were dry. This explains that the flood response was not much bigger than those of the 1954, 2002 and 2013 floods even though the event precipitation was more than $50 \%$ higher in many catchments. At the Weißbach station (near Lofer), the maximum two-day precipitation total was $329 \mathrm{~mm}(12-13$ September 1899) and only a small fraction of it fell as snow (Lauda, 1900). 

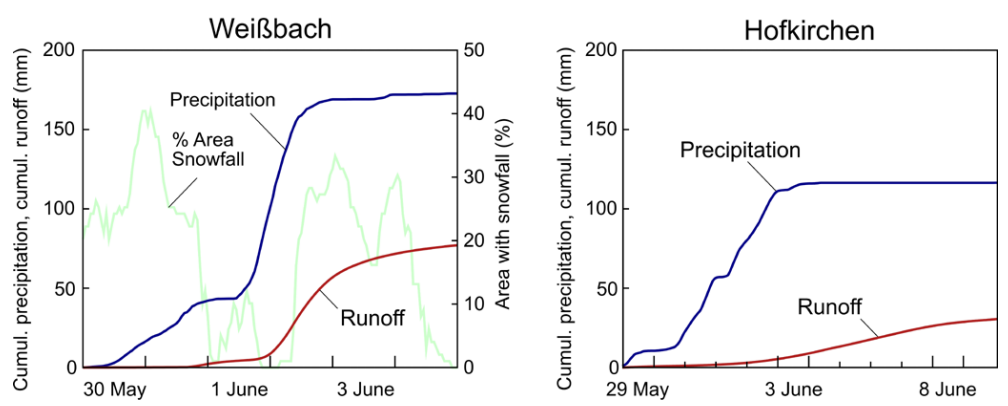

Fig. 6. Cumulative precipitation (blue lines) and cumulative runoff depths (red lines, direct runoff only) for the June 2013 flood event. Light green line in the left panel shows the catchment area with temperatures below $0{ }^{\circ} \mathrm{C}$. (left) Weißbach catchment $\left(567 \mathrm{~km}^{2}\right)$, (right) $\mathrm{Hofkirchen}$ catchment $\left(45610 \mathrm{~km}^{2}\right)$.
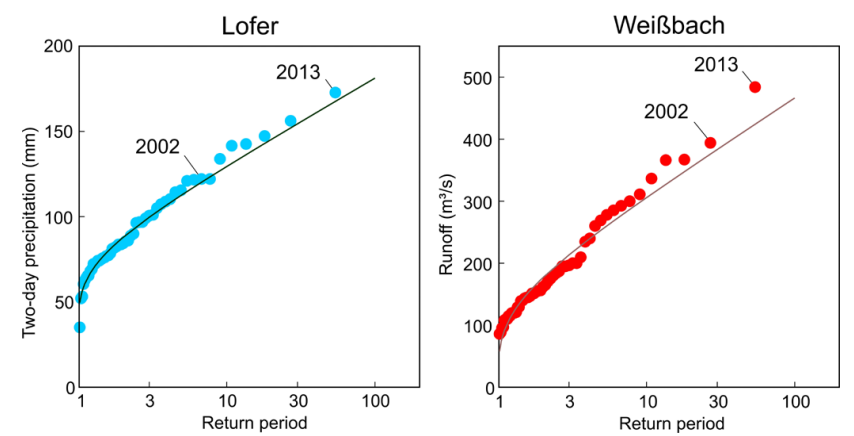

Fig. 7. (left) Statistical analysis of annual maximum precipitation (48 h totals, 07:00-07:00) for the Lofer rain gauge near Weißbach. (right) Statistical analysis of annual maximum runoff for Weißbach $\left(567 \mathrm{~km}^{2}\right)$. Lines show fitted Gumbel distributions. Lofer data 1961-2013. Weißbach data 1959-2013. The 1954 and 1899 precipitation depths of 233 and $329 \mathrm{~mm}$, respectively, are not included in the figure.

\section{Flood wave propagation and confluence}

\subsection{Spatial flood hydrograph patterns of the $2013 \mathrm{flood}$}

The spatio-temporal rainfall patterns of the 2013 flood, combined with differences in runoff response characteristics between the catchments (Gaál et al., 2012), produced complex patterns of runoff hydrographs within the Upper Danube Basin. Figure 8 gives an overview of the evolution of the flood with the basin.

At the Bavarian Danube in the northwest of the basin, the flood response was delayed with relatively flat peaks, similar to previous floods (e.g. 2002, 1954, 1899). This is because of the highly permeable subsurface. However, the total volume of the 2013 flood along the Bavarian Danube was exceptionally large because of the high rainfall and very high antecedent soil moisture, particular in the northern tributaries Vils, Naab and Regen. There were major contributions from the Isar and the Lech originating in the Alps where rainfall was even higher.
The Inn exhibited a much faster response as is always the case with this type of regional floods. The Upper Inn showed very little flood runoff and the flood wave built up through tributaries in Bavaria. The flood wave of the Inn at Wasserburg merged with the Salzach wave, peaking essentially at the same time, and produced a very steep wave at Schärding. There was relatively little flood retention along the Inn before the confluence but a number of small tributaries such as the Rott $\left(280 \mathrm{~m}^{3} \mathrm{~s}^{-1}\right.$ peak flow associated with a return period around $50 \mathrm{yr}$ ) contributed to the magnitude of the flood. At Schärding the flood peaked at 15:00 on 3 June with a discharge of about $5950 \mathrm{~m}^{3} \mathrm{~s}^{-1}$, which represents an estimated return period of about $100 \mathrm{yr}$.

The confluence of the Inn with the Bavarian Danube at Passau resulted in a characteristic, combined shape of the flood wave at Achleiten where the fast and slow contributions of Inn and Danube are clearly visible. During the propagation of the flood wave along the Austrian Danube, it changed shape due to retention in the flood plains, which is apparent by the kink of the rising limb about a day before the peak. Inflow from southern tributaries along the Austrian reach of the Danube, including the Traun, Enns and Ybbs, gave rise to an early secondary peak, indicating that these tributaries peaked much earlier and hardly contributed to peak flows along the Danube. While the flood peaked on 2 June at 20:00 in both Wasserburg and Oberndorf, it peaked on 6 June at 05:00 in Wildungsmauer close to the Austrian-Slovak border.

\subsection{Confluence at Passau of the 2013 flood and comparison with the 2002, 1954, 1899 floods}

The confluence of the peaky flood wave from the Inn with the more delayed flood wave from the Bavarian Danube at Passau is a crucial element in the flood characteristics of the Upper Danube. During the 2013 flood, the inundation level in Passau was enormous (12.89 m) (BfG, 2013). It was of the same order of magnitude as the 1501 flood event (between 12.70 and $13.20 \mathrm{~m}$, depending on the source, Schmidt, 2000; $\mathrm{BfG}, 2013$ ) which is considered the highest flood in the past millennium (Kresser, 1957). 


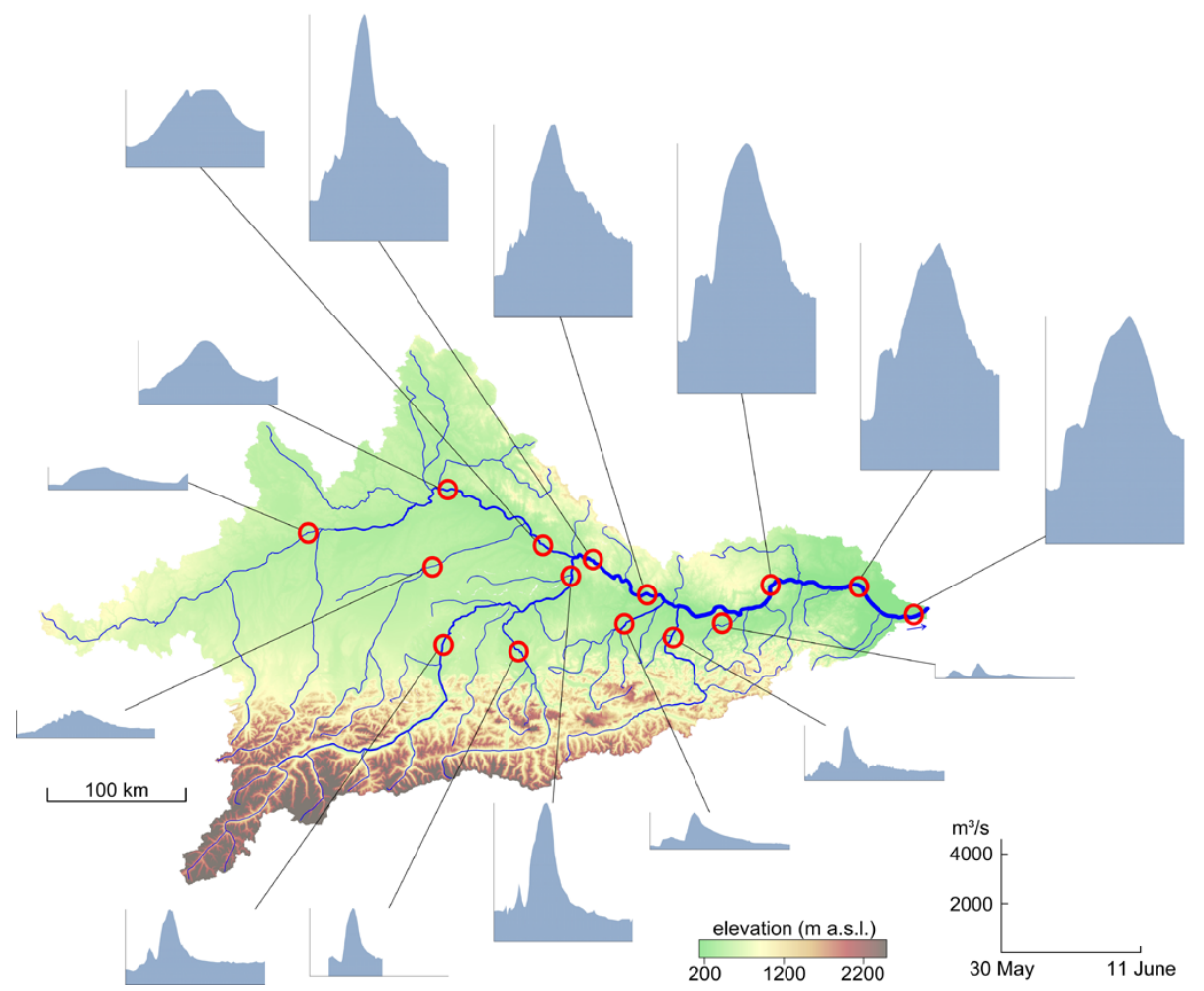

Fig. 8. Propagation of the June 2013 flood along the stream network of the Danube Basin. Red circles indicate the stream gauges as in Fig. 1. The scale shown on the bottom right relates to all hydrographs (light blue areas).

To understand the particularly large flood levels in Passau with implications downstream, Fig. 9 shows the flood hydrographs for stream gauges at the Inn and Danube just above the confluence (Schärding and Hofkirchen/Vilshofen), as well as just below the confluence (Achleiten). For the 2013 and 2002 floods the discharges are given, while for the 1954 and 1899 floods the water levels are given, since reconstruction of the complete runoff hydrograph is prone to uncertainties. It is clear that the Inn flood wave is always much faster than that from the Bavarian Danube. In 2013, the flood wave of the Bavarian Danube (at Hofkirchen) arrived somewhat earlier than usual, as compared to the Inn flood wave. This is because rainfall started a little earlier (on 29 May, rather than on 30 May, as in the Inn catchment) and because of the very high antecedent soil moisture. On 4 June, 2013, a dam along the Bavarian Danube and the Isar collapsed and caused large spatial flooding in Deggendorf, $30 \mathrm{~km}$ upstream of Hofkirchen. This explains the kink in the runoff hydrograph and the flat crest of the flood wave.

In terms of the confluence, the June 2013 flood was most similar to the July 1954 flood when the Bavarian Danube had similarly large flood discharges. At Hofkirchen (and the nearby Vishofen gauge) the 2013 and 1954 peaks were 3420 and $3320 \mathrm{~m}^{3} \mathrm{~s}^{-1}$, respectively. The 2013 peaks were slightly larger due to three main reasons. (i) In 2013 it was warmer than in 1954 with less snowfall, so relatively more rain was available for runoff generation; (ii) in 2013 rainfall was more concentrated along the northern fringe of the Alps where infiltration capacity is lower than in the north of the basin, where much of the rain fell in 1954; and (iii) antecedent soil moisture in the north was probably higher in 2013 than in 1954.

During the 2013 flood event, the wave from the Bavarian Danube arrived comparatively early. At the time Schärding peaked, Hofkirchen showed a discharge of $3000 \mathrm{~m}^{3} \mathrm{~s}^{-1}$ which was close to its peak discharge of $3420 \mathrm{~m}^{3} \mathrm{~s}^{-1}$. With smaller differences in the time lag between the Bavarian Danube and Inn waves as well as larger discharges in the Bavarian Danube, the resulting flood wave was significantly higher than in $1954\left(10000 \mathrm{~m}^{3} \mathrm{~s}^{-1}\right.$ peak flow in Achleiten in 2013 as compared to $9100 \mathrm{~m}^{3} \mathrm{~s}^{-1}$ in 1954).

2002 was different in that the Bavarian Danube flood wave was more delayed, so the superposition was less efficient than in 2013 and 1954. The Inn wave was smaller too because of less rainfall in the catchment area. The 2002 flood was therefore much smaller in Passau, but received major contributions from the tributaries along the Austrian reach of the Danube (including the Kamp, Aist, Traun and Enns) as illustrated by Fig. 10.1 in Blöschl et al. (2013a). Similarly, the 1899 flood was much smaller at the Bavarian Danube because of less rainfall and dry soils. The 1899 flood was most 

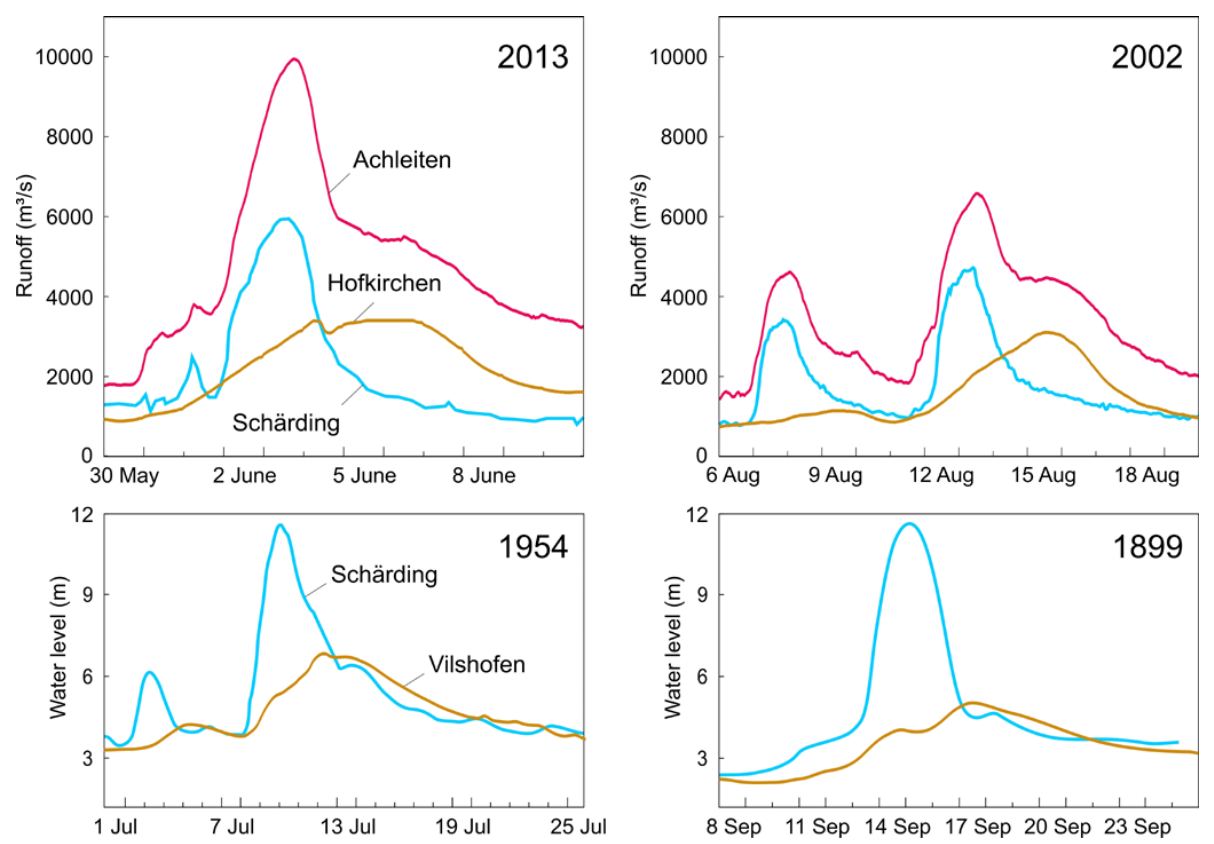

Fig. 9. (top) Runoff hydrographs for the June 2013 and August 2002 events at the confluence of the Inn (Schärding) and the Bavarian Danube (Hofkirchen). Runoff at Achleiten is the sum of Schärding and Hofkirchen plus the Ilz, a minor tributary. (bottom) Water level hydrographs for the July 1954 and September 1899 events at similar locations (Vilshofen is close to Hofkirchen). The 1954 peak discharges at Schärding and Vilshofen were 6300 and $3320 \mathrm{~m}^{3} \mathrm{~s}^{-1}$, respectively, and the 1899 peak discharges were 6400 and $2370 \mathrm{~m}^{3} \mathrm{~s}^{-1}$, respectively.

severe along the Inn, the Traun and the Enns as indicated by the rainfall distribution in Fig. 3.

\subsection{Propagation of the 2013 flood along the Austrian Danube and comparison with 2002, 1954, 1899}

After the confluence of the Bavarian Danube and the Inn at Passau, the 2013 flood wave travelled down the Austrian Danube, changing shape and shifting the timing. Figure 10 shows the time evolution of the peak flow from Passau to Wildungsmauer close to the Austrian-Slovak border. For this reach, the total time lag of the peak during the 2013 flood was $60 \mathrm{~h}$. The celerity of the flood wave is related to two main factors, (i) the rainfall distribution and hence the contribution and timing of the tributaries, and (ii) the flood propagation of the main wave itself and the associated retention in the flood plains. The propagation of the 1954 flood was much slower than that of the other events (118 h, Fig. 10). This is because much of the rainfall occurred in the Bavarian Danube catchment (Fig. 3) with relatively minor contributions from the southern tributaries Traun and Enns, and hardly any contributions from Kamp and Ybbs. Also, there were significant inundations in the flood plains, particularly upstream and downstream of the Linz, contributing to the delay. In contrast, 2002 was the fastest event because those tributaries contributed significantly to the rising limb and peak of the flood wave, thus apparently accelerating the flood propagation, in particular the first wave (2002-1). The 2013 flood was in between 1954 and 1899 in terms of rainfall distribution, so from that perspective one would expect celerities between 1954 and 1899 , i.e. a total time lag of around 80 to $90 \mathrm{~h}$. However, the wave celerity was somewhat faster than that. During the 1899 flood, a total area of $1070 \mathrm{~km}^{2}$ was inundated along the Austrian Danube and tributaries as estimated by Lauda (1900). With an assumed average inundation depth of $2 \mathrm{~m}$, this area corresponds to a total retention volume of more than 2 billion $\mathrm{m}^{3}$. This is very significant relative to the volume of the 1899 flood $\left(6.6\right.$ billion $\mathrm{m}^{3}$, without base flow, Lauda, 1900), indicating that the retention effect was indeed very important during that event. As compared to 1899 , the retention volume had been decreased significantly by 2013 because of flood protection levees, hydropower projects and mobile flood protection. The smaller retention volumes, and possibly the greater water depths in the reservoirs of the runon-river power plants, have likely contributed to accelerating the flood wave, although detailed hydrodynamic studies would be needed to exactly ascertain the reasons for the changes in the wave celerities (e.g. Fischer-Antze et al., 2008). Detailed analyses of observed flood celerities at the Danube are provided in Szolgay and Danáčová (2007) and Mitkova et al. (2005).

\subsection{Magnitude of the 2013 flood at the Austrian Danube and comparison with 2002, 1954, 1899}

Figure 11 shows the extreme value statistics of the maximum annual floods for two stream gauges along the Austrian Danube, the Kienstock and Korneuburg gauges. Korneuburg 


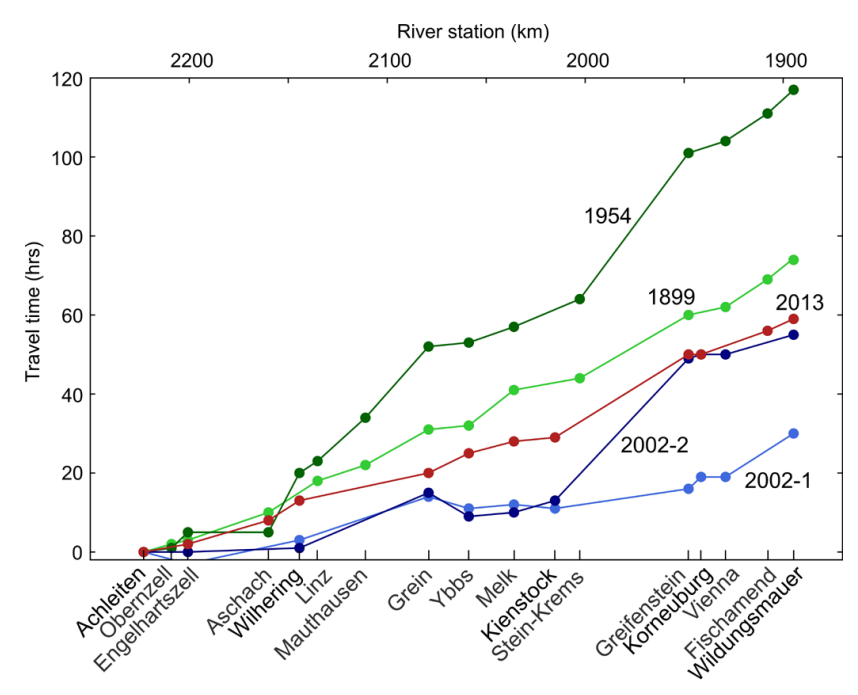

Fig. 10. Travel times of the 2013, 2002, 1954 and 1899 floods along the Austrian reach of the Danube from Achleiten near Passau to Wildungsmauer near the Slovak-Austrian border. 2002-1 and 2002-2 relate to the first and second flood waves of the 2002 event, respectively. At Passau/Achleiten the flood peaks occurred on 3 June, 2013, 18:00; 8 August, 2002, 02:00; 13 August, 2002, 12:00; 10 July, 1954, 08:00; and 15 September 1899, 10:00, which has been plotted as 0 for the five floods in the figure.

is about $12 \mathrm{~km}$ upstream of Vienna, while Kienstock is about $85 \mathrm{~km}$ upstream of Vienna. Even though the spatial distribution of precipitation, runoff generation and the spatial evolution of the 2013 and 2002 floods were different, the maximum runoff values along the Austrian Danube were quite similar. The flood runoff of both events was associated with return periods on the order of $100 \mathrm{yr}$, based on the statistical analysis. The 2013 flood runoff was clearly larger than that of the 1899 and 1954 floods.

It is interesting to compare the relative magnitudes of the peak runoff of these events between the two locations. While at Kienstock the 2013 flood runoff peak was almost identical to that of 2002, at Korneuburg the 2002 peak was significantly lower. In 2013, the peak runoff only decreased slightly along this reach (Kienstock $11100 \mathrm{~m}^{3} \mathrm{~s}^{-1}$, Korneuburg $11055 \mathrm{~m}^{3} \mathrm{~s}^{-1}$ ). In 2002, this decrease was much stronger $\left(11300\right.$ vs. $\left.10250 \mathrm{~m}^{3} \mathrm{~s}^{-1}\right)$. At first sight this is counterintuitive, as the 2002 flood had substantial inflows along the Kienstock-Korneuburg reach (in particular from the Kamp, Figs. 1, 4) while the inflows during the 2013 event were much smaller. The smaller peak attenuation is due to two main reasons. (i) Both events, 2002 and 2013, had two precipitation blocks. However, in 2013 the time period between the blocks was only a few hours, while it was four days in 2002. The 2002 event had two atmospheric rainfall producing situations with movement in between due to less atmospheric stationarity than in 2013. Because of the short interstorm period, the two precipitation blocks in 2013
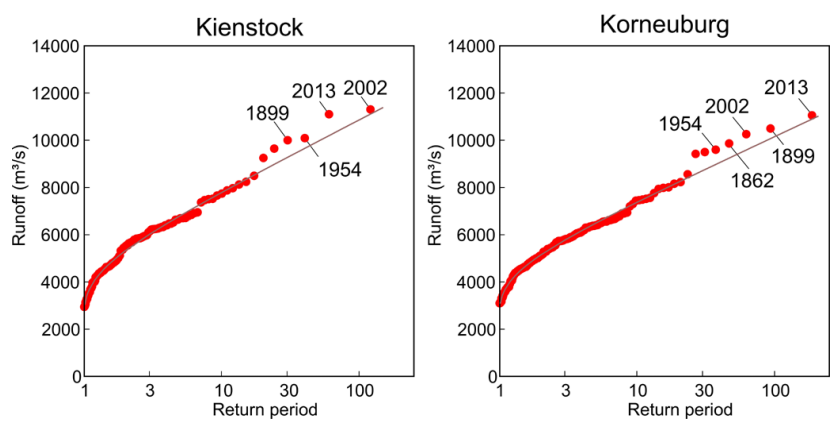

Fig. 11. Statistical analysis of annual maximum runoff for Kienstock (95970 km², left) and Korneuburg (101536 km², right). Lines show fitted Gumbel distributions. Kienstock data 1893-2013, Korneuburg data 1828-2013. Kienstock is a combined series with the nearby Stein-Krems gauge; Korneuburg is a combined series with the nearby Vienna gauge.

combined to a single flood wave on the Danube which exhibited a larger runoff volume than either of the two 2002 events. This is illustrated in Fig. 12 by the flood hydrographs of the 2002 and 2013 flood events at Kienstock and Korneuburg. During the 2013 flood at Kienstock, a runoff threshold of $9000 \mathrm{~m}^{3} \mathrm{~s}^{-1}$ was exceeded during $81 \mathrm{~h}$, while in 2002 the same discharge was only exceeded in $52 \mathrm{~h}$, so the flood volume to be stored in the flood plains was smaller in 2002 resulting in a bigger peak reduction. (ii) Second, there were differences in the performance of the levees and the way the hydraulic structures were operated along the Danube. In the aftermath of the 2002 flood, levees had been strengthened, which resulted in relatively less inundation along the reach in 2013 as compared to 2002 possibly contributing to a smaller peak reduction. Again, detailed hydrodynamic studies would be needed to analyse the effects of individual hydraulic structures.

Overall, the flood volumes at Korneuburg (near Vienna) were enormous for all four floods. The total runoff volume of the 2013 flood from 31 May to 17 June (including base flow) was 9.5 billion $\mathrm{m}^{3}$, the volume of the 2002 flood from 11 to 26 August (second event only) was 6.5 billion $\mathrm{m}^{3}$, and the volumes of the 1954 and 1899 floods (8-27 July and 10-28 September) were 9.9 and 8.5 billion $\mathrm{m}^{3}$, respectively.

\section{Lessons learnt and implications}

\subsection{Implication for hydrological research and design flood estimation}

The June 2013 flood came at a time when the 2002 flood had still been fresh in the minds of hydrologists. The lessons learnt from the 2013 flood therefore complement those learnt from the 2002 flood. From a hydrological perspective, the analysis of the causal factors in this paper highlights the outstanding role of the combination of extreme factors that 


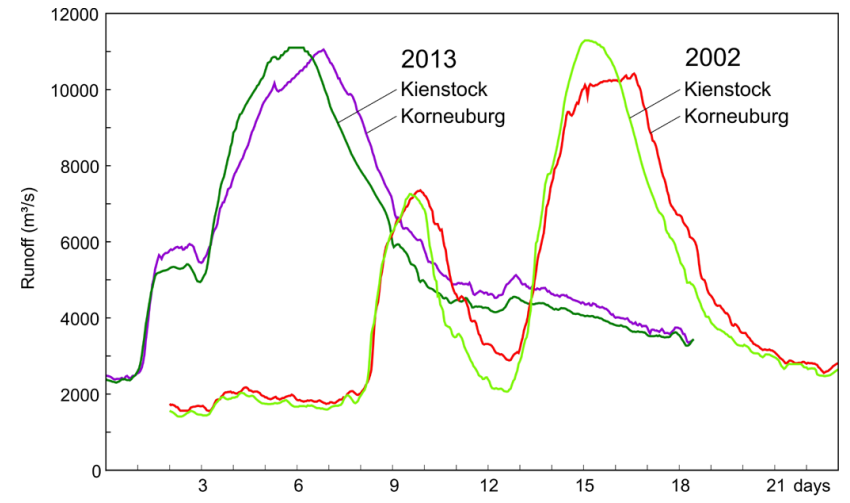

Fig. 12. Comparison of the 2013 flood (dark colours) and the 2002 flood (light colours) for the Kienstock and Korneuburg stream gauges at the Danube which are $73 \mathrm{~km}$ apart.

control the magnitude and characteristics of extreme floods. Indeed, the 2013 flood has had a number of characteristics that contributed to increasing its magnitude, in particular relatively high antecedent soil moisture, little shift between the flood peaks at the confluence of the Bavarian Danube and the Inn, and rainfall blocks close together resulting in a single, large volume flood wave with relatively small peak attenuation. While the important role of the combination of a number of extreme factors has been already emphasised in the past (Kresser, 1957; Gutknecht 1994), the combination of factors remains an essential concept for understanding the magnitude of large, regional floods. On the other hand, there were also factors that could have easily been more extreme. There was less total precipitation than in 1899 and, in the Alpine area, there was a significant snowfall component which retained some of the water in the catchments. Clearly, more extreme situations are possible from a hydrological perspective, albeit unlikely. Rainfall as in 1899 with high antecedent soil moisture as in 2013 would produce a significantly larger flood. This has important implications for estimating design flood values. While statistical analyses are important when estimating design flood discharges, particularly in large catchments with long flood records, it is equally important to address the problem from a process perspective and understand what combinations of factors could plausibly be expected to occur during extreme situations. This is in the spirit of flood frequency hydrology, a framework for understanding and estimating flood discharges by combining local flood data with additional types of information: temporal information on historic floods, spatial information on floods in neighbouring catchments, and causal information on the flood processes (Merz and Blöschl, 2008a, b; Viglione et al., 2013; Gaál et al., 2010). The German guidelines, for example (DWA, 2012), explicitly recommend including temporal, spatial and causal information to complement the local, systematic flood data in the analysis.
Another notable feature of the 2013 flood is that it exceeded the largest flood runoff observed in the past two centuries in many parts of the Upper Danube Basin and one may wonder whether such an extreme flood, shortly after the 2002 flood, is an indicator of increasing flood magnitudes in the Upper Danube. There are three main factors that potentially contribute to changes in regional floods related to climate, catchment processes, and the river network (Merz et al., 2012). Change in climate has attracted substantial recent discussion related to increases in rainfall extremes (Blöschl and Montanari, 2010; Kundzewic, 2012). Some indicators such as weather patterns (Petrow et al., 2009) and flood seasonality (Parajka et al., 2009, 2010) do point to changes in the atmospheric system in Europe, but the issue is far from resolved and it is not clear how to model such changes reliably (Merz et al., 2011; Peel and Blöschl, 2011). However, it seems clear that extreme floods do not arrive randomly but cluster in time into flood-poor and flood-rich periods consistent with the Hurst effect (Jain and Lall, 2001; Khaliq et al., 2006; Szolgayova et al., 2013). Changes in catchment processes include land use changes. Their effect is usually quite local as in urban floods, but less important for regional floods (Blöschl et al., 2007). Also, the importance of land use tends to decrease with the magnitude of the events (Salazar et al., 2012). Changes along the river network are more tangible. Levees have been built along the Danube and tributaries in the past two centuries, thereby reducing potential retention volumes in the flood plains (Szolgay et al., 2008). Additionally, hydraulic structures such as reservoirs of run-on-river power plants, river regulation projects and changes in stream morphology will contribute to changes in the flood propagation. An example of the latter is the stream bed degradation of the Traun River between 1899 and 1954 of about $60 \mathrm{~cm}$, leading to significantly less flood inundation in 1954 as compared to 1899 at the Traun (Kresser, 1954). Also, as the flood waves change their celerities, the modified relative timings at confluences may alter the characteristics of the flood. Again, a process-based analysis is needed that accounts for the interplay of these effects. In the FloodChange project these changes are analysed in detail on the basis of the flood frequency hydrology concept of combining local flood data with historic floods, and spatial and causal flood information (Merz and Blöschl, 2008a).

\subsection{Implications for flood risk management}

While there was significant damage during the 2013 flood there is no doubt that, overall, the flood protection measures put into place throughout the past two centuries have vastly reduced the damage relative to a scenario without protection. Historically, much of the mitigation activities have focused on structural measures such as levees, but there is an increasing awareness that a number of flood management measures are needed to complement each other (Merz et al., 2010a, b; Sayers et al., 2013). These include structural measures such 
as levees for flood protection and construction of polders for flood retention, and non-structural measures such as spatial planning and increasing the preparedness of local citizens. Retaining water in polders and retention basins is always useful as, even for extreme flooding, flood attenuation will occur with positive effects downstream. The drawback is that a lot of area is needed for flood retention to be effective for large rivers such as the Danube, as the flood peak reduction is a direct function of the available storage volume relative to the flood volume. In highly populated areas it is difficult to make sufficiently large areas available, so levees will continue to play a central role in flood management. However, levees may exacerbate flood risk downstream. Integrated flood risk management therefore considers the river basin as a whole as stipulated by the EU flood risk directive (EU, 2007).

Local protection of buildings, along with raising flood risk awareness and preparedness of local citizens, may be highly effective to complement the other measures. For these, and other flood event management measures such as early evacuation and reliable warning systems driven by hydrological forecast models are needed. The maximum water level of the 2013 flood was in fact predicted very well along the Austrian Danube for lead times between 24 and $48 \mathrm{~h}$ (depending on the location), although the wave celerity was overestimated (Blöschl et al., 2013c). While large-scale meteorological models and satellites provide important inputs, in particular on future precipitation, capturing the local hydrological situation is essential for accurately modelling floods (Blöschl, 2008). Increasingly longer lead times are expected from warning agencies, which requires the estimation of forecast uncertainties to quantify the confidence one has in the predictions (Cloke and Pappenberger, 2009; Laurent et al., 2010; Komma et al., 2008; Nester et al., 2012). However, communicating these uncertainties remains a challenge. Visualisation tools are one potential avenue towards assisting the communication (Ribicic et al., 2013; Hlavcová et al., 2005).

These flood management activities are important for all floods that exceed bank full discharge and potentially produce damage. Extreme floods, exceeding the June 2013 flood in magnitude, however, require special attention. A flood produced by the 1899 rainfall with 2013 antecedent soil moisture is within the realm of thinkable situations, although its probability will be small. Some of the flood management activities will no longer be effective for a flood of that magnitude. Instead, there is a need for an increased focus on reducing the vulnerability of the system (Prudhomme et al., 2010; van Pelt and Swart, 2011; Blöschl et al., 2013b). Such measures may not be optimum in an economic sense but may be more robust than alternative approaches if a flood goes beyond the limits of past experience. For example, the vulnerability can be reduced by designing spillways for levees and by allowing for redundancy in warning systems and emergency plans. It is not unusual for the power system to fail during extreme floods, so redundancy is indeed important.
Land use planning and resettling activities to reduce the value of assets in flood prone area will also contribute to reducing the vulnerability. Participative processes are needed for such activities to find acceptability in a socio-economic context (Carr et al., 2012). From a long-term perspective, the interplay of socio-economic processes with hydrological processes is complex (Sivapalan et al., 2012; Di Baldassarre et al., 2013). In reducing vulnerability one may therefore start with the policy options at the local scale and explore a wide range of possibilities causing extreme floods, including combinations of unfavourable factors, and options for managing them. The flood risk management study of Wardekker et al. (2010) is an example that explores imaginable surprises, something they term "wildcards", to develop a strategy of strengthening the resilience of the city of Rotterdam. A resilience approach may make the system less prone to disturbances and enable quick responses to make it capable of dealing with extremes. For such extremes, as with all floods, the hallmark of integrated flood risk management is the interplay of all measures in a seamless way. Comparative flood analysis studies as presented in this paper are an essential basis for developing more efficient strategies for integrated flood risk management.

\section{Appendix A}

\section{Catchment characteristics}

Table A1. Catchment area and mean elevation of the catchments used in this paper (Fig. 1).

\begin{tabular}{llrr}
\hline Stream gauge & Stream & $\begin{array}{r}\text { Catchment } \\
\text { area }\left(\mathrm{km}^{2}\right)\end{array}$ & $\begin{array}{r}\text { Mean elevation } \\
\text { (m a.s.l.) }\end{array}$ \\
\hline Achleiten & Danube & 76650 & 829 \\
Donauwörth & Danube & 15100 & 640 \\
Greimpersdorf & Ybbs & 1100 & 676 \\
Hofkirchen & Danube & 45610 & 622 \\
Kienstock & Danube & 96000 & 817 \\
Korneuburg & Danube & 101500 & 803 \\
Landshut & Isar & 7900 & 702 \\
Obergäu & Lammer & 395 & 1195 \\
Oberndorf & Salzach & 6120 & 1338 \\
Rosenheim & Mangfall & 1090 & 790 \\
Schärding & Inn & 25665 & 1257 \\
Schwabelweis & Danube & 35450 & 614 \\
St. Johann & Kitzbüheler Ache & 330 & 1312 \\
Staudach & Tiroler Achen & 944 & 1148 \\
Steyr & Enns & 5915 & 1138 \\
Wasserburg & Inn & 11980 & 1674 \\
Weißbach am Lofer & Saalach & 567 & 1346 \\
Wels & Traun & 3425 & 819 \\
Wildungsmauer & Danube & 104000 & 784 \\
Wilhering & Danube & 76450 & 820 \\
\hline
\end{tabular}


Acknowledgements. We would like to thank all the institutions that provided data, particularly the Hydrologic Offices and the Central Institute for Meteorology and Geodynamics. All data of the 2013 flood are tentative. We would also like to thank the ERC (Advanced Grant on FloodChange) and the FWF (project no P 23723-N21) for financial support.

Edited by: F. Pappenberger

\section{References}

BfG: Das Juni-Hochwasser des Jahres 2013 in Deutschland (The 2013 June flood in Germany), BfG Report no. 1793, Federal Institute of Hydrology, Koblenz, Germany, 2013.

Blöschl, G.: Flood warning - on the value of local information, Int. J. River Basin Manage., 6, 41-50, 2008.

Blöschl, G. and Montanari, A.: Climate change impacts-throwing the dice?, Hydrol. Process., 24, 374-381, 2010.

Blöschl, G., Ardoin-Bardin, S., Bonell, M., Dorninger, M., Goodrich, D., Gutknecht, D., Matamoros, D., Merz, B., Shand, P., and Szolgay, J.: At what scales do climate variability and land cover change impact on flooding and low flows?, Hydrol. Process., 21, 1241-1247, 2007.

Blöschl, G., Sivapalan, M., Wagener, T., Viglione, A., and Savenije, H. H. G. (Eds.): Runoff Prediction in Ungauged Basins - Synthesis across Processes, Places and Scales, Cambridge University Press, Cambridge, UK, 465 pp., 2013 a.

Blöschl, G., Viglione, A., and Montanari, A.: Emerging approaches to hydrological risk management in a changing world, in: Climate Vulnerability: Understanding and Addressing Threats to Essential Resources, Elsevier Inc., Academic Press, 3-10, $2013 \mathrm{~b}$.

Blöschl, G., Nester, Th., Komma, J., Parajka, J., and Perdigão, R. A. P.: Das Juni-Hochwasser 2013 - Analyse und Konsequenzen für das Hochwasserrisikomanagement (The June 2013 flood - analysis and implications for flood risk management), Österreichische Ingenieur- und Architekten-Zeitschrift, 158, 141-152 , 2013c.

BLU (Bayerisches Landesamt für Umwelt): August - Hochwasser 2005 in Südbayern (August 2005 flood in Southern Bavaria), Endbericht vom 12 April 2006, Bayerisches Landesamt für Umwelt, München, 49 pp., 2006.

BMU: Hydrologischer Atlas von Deutschland (Hydrological Atlas of Germany), Bundesministerium für Umwelt, Naturschutz und Reaktorsicherheit, Koblenz, 2003.

Carr, G., Blöschl, G., and Loucks, D. P.: Evaluating participation in water resource management: A review, Water Resour. Res., 48, W11401, doi:10.1029/2011WR011662, 2012.

Cloke, H. L. and Pappenberger, F.: Ensemble flood forecasting: A review, J. Hydrol., 375, 613-626, 2009.

Deutsche Vereinigung für Wasserwirtschaft, Abwasser und Abfall (DWA): Merkblatt Ermittlung von Hochwasserwahrscheinlichkeiten (Guidelines for estimating flood probabilities), DWAM. 552, Hennef, Germany, 2012.

Di Baldassarre, G., Viglione, A., Carr, G., Kuil, L., Salinas, J. L., and Blöschl, G.: Socio-hydrology: conceptualising humanflood interactions, Hydrol. Earth Syst. Sci., 17, 3295-3303, doi:10.5194/hess-17-3295-2013, 2013.
EU: The European Parliament and the Council of the European Union. Directive 2007/60/EC of the European Parliament and the Council of 23 October 2007 on the assessment and management of flood risks, Off. J. Eur. Union, L288/27-L288/34, 2007.

Fischer-Antze, T., Olsen, N. R. B., and Gutknecht, D.: Threedimensional CFD modeling of morphological bed changes in the Danube River, Water Resour. Res., 44, W09422, doi:10.1029/2007WR006402, 2008.

Gaál, L., Szolgay, J., Kohnová, S., Hlavcová, K., and Viglione, A.: Inclusion of historical information in flood frequency analysis using a Bayesian MCMC technique: a case study for the power dam Orlík, Czech Republic, in: Contributions to Geophysics and Geodesy, ISSN 1335-2806, Vol. 40, 121-147, 2010.

Gaál, L., Szolgay, J., Kohnová, S., Parajka, J., Merz, R., Viglione, A., and Blöschl, G.: Flood timescales: Understanding the interplay of climate and catchment processes through comparative hydrology, Water Resour. Res., 48, W04511, doi:10.1029/2011WR011509, 2012.

Godina, R., Lalk, P., Lorenz, P., Müller, G., and Weilguni, V.: Die Hochwasserereignisse im Jahr 2002 in Österreich (The flood events of 2002 in Austria), Mitt. Hydrogr. Dienstes Österreich, 82, 1- 39, 2003.

Gutknecht, D.: Extremhochwässer in kleinen Einzugsgebieten (Extreme floods in small catchments), Österreichische Wasser- und Abfallwirtschaft, 46, 50-57, 1994.

Gutknecht, D., Reszler, Ch., und Blöschl, G.: Das Katastrophenhochwasser vom 7. August 2002 am Kamp - eine erste Einschätzung (The 7 August 2002 - flood of the Kamp - a first assessment), Elektrotechnik und Informationstechnik, 119, 411413, 2002.

Haiden, T., Kann, A., Wittmann, C., Pistotnik, G., Bica, B., and Gruber, C.: The integrated nowcasting through comprehensive analysis (INCA) system and its validation over the eastern Alpine region, Weather Forecast., 26, 166-183, 2011.

Hlavcová, H., Kohnova, S., Kubeš, R., Szolgay, J., and Zvolensky, M.: An empirical method for estimating future flood risks for flood warnings, Hydrol. Earth Syst. Sci., 9, 431-448, doi:10.5194/hess-9-431-2005, 2005.

Holton, J. R.: An introduction to Dynamic Meteorology, Elsevier, 4th Edition, 535 pp., 2004.

HZB: Das Juli-Hochwasser 1954 im österreichischen Donaugebiet (The July 1954 flood in the Austrian Danube basin), Beiträge zur Hydrographie Österreichs, Nr. 29, Hydrogr. Zentralbüro Wien, 139 pp., 1955.

Jain, S. and Lall, U.: Floods in a changing climate: Does the past represent the future?, Water Resour. Res., 37, 3193-3205, 2001.

Janoschek, W. R. and Matura, A.: Outline of the Geology of Austria, Abb. Geol. B.-A., 26e, 7-98, 1980.

Khaliq, M. N., Ouarda, T. B. M. J., Ondo, J.-C., Gachon, P., and Bobée, B.: Frequency analysis of a sequence of dependent and/or non-stationary hydro-meteorological observations: A review, J. Hydrol., 329, 534-552, 2006.

Kistler, R., Kalnay, E., Collins, W., Saha, S., White, G., Woollen, J., Chelliah, M., Ebisuzaki, W., Kanamitsu, M., Kousky, V., van den Dool, H., Jenne, R., and Fiorino, M.: The NCEP-NCAR 50Year Reanalysis: Monthly Means CD-ROM and Documentation, B. Am. Meteorol. Soc., 82, 247-268, 2001. 
Komma, J., Reszler, C., Blöschl, G., and Haiden, T.: Ensemble prediction of floods - catchment non-linearity and forecast probabilities, Nat. Hazards Earth Syst. Sci., 7, 431-444, doi:10.5194/nhess-7-431-2007, 2007.

Komma, J., Blöschl, G., and Reszler, C.: Soil moisture updating by Ensemble Kalman Filtering in real-time flood forecasting, J. Hydrol., 357, 228-242, 2008.

Kresser, W.: Der Einfluß der Regulierungs- und Kraftwerksbauten auf die Hochwasserverhältnisse der österreichische Donau (Effect of river training and power plants on the floods of the Austrian Danube), Oesterreichische Wasserwirtschaft 6, 65-68, 1954.

Kresser, W.: Die Hochwässer der Donau (The floods of the Danube), Schriftenreihe des österreichischen Wasserwirtschaftsverbandes, 32-33, Wien, 1957.

Kundzewicz, Z. W. (Ed.): Changes in Flood Risk in Europe, IAHS Special Publication 10, IAHS Press, Wallingford, 516 pp., 2012.

Lauda, E.: Die Hochwasserkatastrophe des Jahres 1899 im österreichischen Donaugebiete (The flood disaster of 1899 in the Austrian Danube basin), Beiträge zur Hydrographie Österreichs, IV. Heft, k.k. hydrographisches Central-Bureau, Wien, 1900.

Laurent, S., Hangen-Brodersen, C., Ehret, U., Meyer, I., Moritz, K., Vogelbacher, A., and Holle, F.-K.: Forecast Uncertainties in the Operational Flood Forecasting of the Bavarian Danube Catchment, in: Hydrological Processes of the Danube River Basin, edited by: Brilly, M., Springer, 367-387, 2010.

Merz, B., Kreibich, H., Schwarze, R., and Thieken, A.: Review article "Assessment of economic flood damage", Nat. Hazards Earth Syst. Sci., 10, 1697-1724, doi:10.5194/nhess-10-16972010, 2010a.

Merz, B., Hall, J., Disse, M., and Schumann, A.: Fluvial flood risk management in a changing world, Nat. Hazards Earth Syst. Sci., 10, 509-527, doi:10.5194/nhess-10-509-2010, 2010 b.

Merz, B., Vorogushyn, S., Uhlemann, S., Delgado, J., and Hundecha, Y.: HESS Opinions "More efforts and scientific rigour are needed to attribute trends in flood time series", Hydrol. Earth Syst. Sci., 16, 1379-1387, doi:10.5194/hess-16-13792012, 2012.

Merz, R. and Blöschl, G.: Flood frequency hydrology: 1. Temporal, spatial, and causal expansion of information, Water Resour. Res., 44, W08432, 2008a.

Merz, R. and Blöschl, G.: Flood frequency hydrology: 2. Combining data evidence, Water Resour. Res., 44, W08433, 2008 b.

Merz, R. and Blöschl, G.: A regional analysis of event runoff coefficients with respect to climate and catchment characteristics in Austria, Water Resour. Res., 45, W01405, doi:10.1029/2008WR007163, 2009.

Merz, R., Blöschl, G., and Parajka, J.: Spatio-temporal variability of event runoff coefficients in Austria, J. Hydrol., 331, 591-604, 2006.

Merz, R., Parajka, J., and Blöschl, G.: Time stability of catchment model parameters: Implications for climate impact analyses, Water Resour. Res., 47, W02531, doi:10.1029/2010WR009505, 2011.

Mitkova, V., Pekarova, P., Miklanek, P., and Pekar, J.: Analysis of flood propagation changes in the Kienstock-Bratislava reach of the Danube River, Hydrolog. Sci. J., 50, 655-668, 2005.
Nester, T., Kirnbauer, R., Gutknecht, D., and Blöschl, G.: Climate and catchment controls on the performance of regional flood simulations, J. Hydrol., 402, 340-356, 2011.

Nester, T., Komma, J., Viglione, A., and Blöschl, G.: Flood forecast errors and ensemble spread - a case study, Water Resour. Res., 48, W10502, doi:10.1029/2011WR011649, 2012.

Parajka, J., Merz, R., and Blöschl, G.: Uncertainty and multiple objective calibration in regional water balance modeling - Case study in 320 Austrian catchments, Hydrol. Process., 21, 435446, 2007.

Parajka, J., Kohnová, S., Merz, R., Szolgay, J., Hlavcová, K., and Blöschl, G.: Comparative analysis of the seasonality of hydrological characteristics in Slovakia and Austria, Hydrolog. Sci. J., 54, 456-473, 2009.

Parajka, J., Kohnová, S., Bálint, G., Barbuc, M., Borga, M., Claps, P., Cheval, S., Dumitrescu, A., Gaume, E., Hlavcová, K., Merz, R., Pfaundler, M., Stancalie, G., Szolgay, J., and Blöschl, G.: Seasonal characteristics of flood regimes across the AlpineCarpathian range, J. Hydrol., 394, 78-89, 2010.

Peel, M. C. and Blöschl, G.: Hydrologic modelling in a changing world, Prog. Phys. Geogr., 35, 249-261, 2011.

Pekarová, P., Halmová, D., Bačová-Mitková, V., Miklánek, P., Pekár, J., and Škoda, P: Historic flood marks and flood frequency analysis of the Danube River at Bratislava, Slovakia, J. Hydrol. Hydromech., 61, 326-333, doi:10.2478/johh-2013-0041, 2013.

Petrow, T., Zimmer, J., and Merz, B.: Changes in the flood hazard in Germany through changing frequency and persistence of circulation patterns, Nat. Hazards Earth Syst. Sci., 9, 1409-1423, doi:10.5194/nhess-9-1409-2009, 2009.

Prudhomme, C., Wilby, R., Crooks, S., Kay, A., and Reynard, N.: Scenario-neutral approach to climate change impact studies: Application to flood risk, J. Hydrol., 390, 198-209, 2010.

Ribicic, H., Waser, J., Fuchs, R., Blöschl, G., and Gröller, E.: Visual analysis and steering of flooding simulations. IEEE T. Vis. Comput. Gr., 19, 1062-1075, 2013.

Rossby, C.-G.: Relation between variations in the intensity of the zonal circulation of the atmosphere and the displacements of the semi-permanent centers of action, J. Mar. Res., 2, 38-55, 1939.

Salazar, S., Francés, F., Komma, J., Blume, T., Francke, T., Bronstert, A., and Blöschl, G.: A comparative analysis of the effectiveness of flood management measures based on the concept of "retaining water in the landscape" in different European hydroclimatic regions, Nat. Hazards Earth Syst. Sci., 12, 3287-3306, doi:10.5194/nhess-12-3287-2012, 2012.

Sayers, P. Y. L. I., Galloway, G., Penning-Rowsell, E., Shen, F., Wen, K., Chen, Y., and Le Quesne, T.: Flood Risk Management: A Strategic Approach. Paris, UNESCO, 2013.

Schmidt, M. (Ed.): Hochwasser und Hochwasserschutz in Deutschland vor 1850 (Floods and flood protection in Germany before 1850), Oldenbourd Industrieverlag, Munich, ISBN 3-486-26494x, 280 pp., 2000.

Sivapalan, M., Savenije, H. H. G., and Blöschl, G.: Sociohydrology: A new science of people and water, Hydrol. Process., 26, 1270-1276, 2012.

Szolgay, J. and Danáčová, M.: Detection of changes in the flood celerity by multilinear routing on the Danube, Meteorol. J., 10, 219-224, 2007. 
Szolgay, J., Danáèová, M., Jurèák, S., and Spál, P.: Multilinear flood routing using empirical wave-speed discharge relationships: case study on the Morava River, J. Hydrol. Hydromech., 56, 213-227, 2008.

Szolgayova, E., Laaha, G., Blöschl, G., and Bucher, C.: Factors influencing long range dependence in streamflow of European rivers, Hydrol. Process., online first, doi:10.1002/hyp.9694, 2013.

Ulbrich, U., Brücher, T., Fink, A. H., Leckebusch, G. C., Krüger, A., and Pinto, J. G.: The central European floods of August 2002: Part 1 - Rainfall periods and flood development, Weather, 58, 371-377, 2003.

van Bebber, W. J.: Die Zugstrassen der barometrischen Minima nach den Bahnenkarten der Deutschen Seewarte für den Zeitraum von 1870-1890, Meteorol. Z., 8, 361-366, 1891. van Pelt, S. C. and Swart, R. J.: Climate change risk management in transnational river basins: the Rhine, Water Resour. Manage., 25, 3837-3861, 2011.

Viglione, A., Chirico, G. B., Komma, J., Woods, R., Borga, M., and Blöschl, G.: Quantifying space-time dynamics of flood event types, J. Hydrol., 394, 213-229, 2010.

Viglione, A., Merz, R., Salinas, J. S., and Blöschl, G.: Flood frequency hydrology: 3. A Bayesian analysis, Water Resour. Res., 49, 675-692, 2013.

Wardekker, J. A., de Jong, A., Knoop, J. M., and van der Sluijs, J. P.: Operationalising a resilience approach to adapting an urban delta to uncertain climate changes, Technol. Forecast. Soc., 77, 987-998, 2010. 